\title{
PENGEMBANGAN BAHAN BELAJAR KEAKSARAAN BERBASIS CERITA RAKYAT KUTAI KALIMANTAN TIMUR
}

\author{
Tri Widayati \& O Dollar Sihombing \\ Widayanti \\ e-mail : tri3wid@yahoo.com \\ Pamong Belajar UPTD Pengembangan Kegiatan Belajar Prov. Kalimantan Timur
}

\begin{abstract}
Abstrak: Pengembangan ini bertujuan untuk mengembangkan materi pembelajaran keaksaraan berdasarkan cerita rakyat Kutai Kalimantan Timur dan menguji kelayakan materi pembelajaran. Penelitian dilakukan di PKBM Puteri Karang Melenu Kab. Kutai Kartanegara pada bulan Mei-Oktober 2011. Pengembangan digunakan ADDIE (Analisa, Desain, Mengembangkan, Melaksanakan, Evaluasi) dengan purposive sampling. Uji coba diakukan terhadap materi dan kualitas produk. Bahan uji coba terdiri pra dan pasca kompetensi siswa dan data observasi pembelajaran yang meliputi kompetensi guru dan respon siswa dalam belajar. Sementara data ujicoba kualitas materi pembelajaran membahas kualitas materi, lay out, fungsi, dan bahasa. T-test hasil untuk sampel berpasangan menunjukkan bahwa ada perbedaan yang signifikan antara pre-test skor dan post-test skor siswa setelah materi cerita rakyat yang digunakan belajar. Sementara itu, dari ujicoba kualitas materi pembelajaran, ditemukan bahwa kriteria untuk aspek fungsi sangat baik dan kriteria untuk bahan, layout, dan bahasa juga baik.
\end{abstract}

Kata-kata kunci: materi pembelajaran, literasi, foklore

\section{INSTRUCTIONAL MATERIAL DEVELOPMENT BASED ON FOLKLORE OF KUTAI, EAST KALIMANTAN}

\begin{abstract}
This instructional material development was intended to develop literacy learning material based on Kutai East Kalimantan folklore and examine the approriateness of the learning material. The research was conducted at Community Learning Center of Puteri Karang Melenu, Kutai Kartanegara District, as from May through October 2011. The development model applied ADDIE ( Analysis, Design, Develop, Implement, Evaluate) using purposive sampling technique. T-test result for paired samples showed that there was a significant difference between pre-test score and post-test score of the students after used folklore learning material. Meanwhile, from try-out of learning material quality, it was discovered that the criteria for function aspect was very good and the criteria for material, lay out, and language was good.
\end{abstract}

Keywords: learning material, literacy, folklore

\section{PENDAHULUAN}

Pendidikan keaksaraan merupakan salah satu bentuk layanan pendidikan nonformal bagi masyarakat dalam Sistem Pendidikan Nasional. Dalam Undang-Undang No. 20 tahun 2003 pada pasal 26 ayat 3 , disebutkan bahwa pendidikan nonformal meliputi pendidikan kecakapan hidup, pendidikan anak usia dini, pendidikan kepemudaan, pendidikan perempuan, pendidikan keaksaraan, pendidikan keterampilan dan pelatihan kerja, pendidikan kesetaraan, serta pendidikan lain yang ditujukan untuk mengembangkan kemampuan peserta didik. Pendidikan keaksaraan diselenggarakan untuk memberikan layanan pendidikan yang memenuhi standar kelayakan mutu, proses, hasil, dan dampak sehingga hasilnya dapat dipertanggungjawabkan kepada masyarakat. Layanan pendidikan keaksaraan diperuntukkan bagi semua orang yang belum melek aksara dan melek aksara parsial untuk penguasaan keberaksaraan serta bagi aksarawan baru untuk pemeliharaan keberaksaraan.

Upaya pengentasan buta aksara di Kalimantan Timur telah memberikan hasil yang signifikan. Pada tahun 2009, penduduk buta aksara di Kalimantan Timur berjumlah 51.889 orang dan pada tahun 2010 telah berkurang menjadi 31.623 orang. Artinya terdapat penurunan jumlah buta aksara sampai 60,9\%. Kabupaten Kutai Kartanegara memiliki jumlah buta aksara yang paling banyak, yaitu 13.991 orang, kemudian Kabupaten Passer sebanyak 6.463 orang dan Kabupaten 
Kutai Timur sebanyak 4.303 orang (Dinas Pendidikan Prov. Kaltim, 2010).

Dalam kenyataannya, tidak semua komunitas sasaran pendidikan keaksaraan di Kalimantan Timur dapat dilayani dengan metode dan strategi pembelajaran yang umum dilaksanakan. Hal ini disebabkan karena adanya alasan-alasan khusus seperti adanya faktor-faktor geografis dan hambatan sosial budaya. Termasuk dalam kategori ini adalah masyarakat dengan karakteristik budaya tertentu. Sebagai titik masuk pengembangan pendidikan keberaksaraan masyarakat ini dapat bertolak dari keaksaraan yang hidup di tengah-tengah masyarakat.

Cerita rakyat merupakan salah satu bentuk keaksaraan yang ada di masyarakat, yang menjadi wahana untuk berkomunikasi antara masyarakat lama dengan masyarakat sekarang yang disebarluaskan secara lisan dan tulisan. Pembelajaran keaksaraan dengan menggunakan cerita rakyat sebagai sumber tema diharapkan lebih bermakna dengan dukungan bahan belajar yang dirancang sedemikian rupa agar relevan dengan budaya warga belajar setempat.

Berdasarkan uraian di atas, dapat diidentifikasi beberapa permasalahan dalam pembelajaran keaksaraan, diantaranya:

1. Pada umumnya pembelajaran keaksaraan selama ini didominasi dengan tema-tema fungsional.

2. Tidak semua komunitas sasaran pendidikan keaksaraan di Kalimantan Timur dapat dilayani dengan metode dan strategi pembelajaran yang umum dilaksanakan.

3. Keberadaan cerita rakyat Kalimantan Timur belum dimanfaatkan secara optimal sebagai media pembelajaran.

4. Belum adanya media pembelajaran keaksaraan yang dikembangkan dengan mengangkat cerita rakyat sebagai sumber tema.

Pengembangan ini dibatasi pada masalah belum adanya media pembelajaran keaksaraan yang dikembangkan dengan mengangkat cerita rakyat sebagai sumber tema. Berdasarkan pembatasan masalah tersebut, maka rumusan masalah dalam pengembangan ini adalah bagaimana mengembangkan bahan belajar pembelajaran keaksaraan yang berbasis cerita rakyat yang dapat digunakan pada pendidikan keaksaraan di Kalimantan Timur?

Pengembangan ini bertujuan untuk mengembangkan bahan belajar keaksaraan berbasis cerita rakyat Kutai Kalimantan Timur serta menguji kelayakan bahan belajar keaksaraan yang dikembangkan ditinjau dari aspek pembelajaran, isi, dan tampilan.

Pengembangan bahan belajar keaksaraan ber- basis cerita rakyat Kutai Kalimantan Timur dilakukan karena bermanfaat untuk warga belajar, tutor keaksaraan, dan kelompok belajar. Bagi warga belajar dapat (1) mempermudah penguasaan keterampilan warga belajar dalam peningkatan keterampilan membaca, menulis, berhitung, dan berkomunikasi; (2) menjadikan pembelajaran lebih menarik/menyenangkan sehingga warga belajar termotivasi untuk aktif belajar; dan (3) mendekatkan warga belajar dengan cerita rakyat yang merupakan bagian budaya lokal.

Sedangkan manfaat pengembangan bahan belajar bagi tutor keaksaraan antara lain sebagai alternatif pengayaan jenis bahan belajar dan model pengembangan bahan belajar lain yang sejenis. Hasil pengembangan ini juga diharapkan bermanfaat bagi kelangsungan kelompok belajar, khususnya kelompok belajar keaksaraan Puteri Karang Melenu sebagai tempat uji coba, mengingat belum adanya bahan belajar keaksaraan berbasis cerita rakyat. Hasil pengembangan ini juga dapat dijadikan sebagai salah satu model dalam melakukan inovasi media pembelajaran yang lain dalam upaya meningkatkan kualitas pembelajaran keaksaraan.

\section{Kajian Teoretis}

\section{Pendidikan keaksaraan}

Keaksaraan merupakan alat yang sangat diperlukan agar dapat berpartisipasi secara efektif dalam kehidupan sosial dan ekonomi yang akan mengarah pada pembangunan sumber daya manusia dan pengentasan kemiskinan. Keaksaraan sangat terkait dengan peradaban manusia berupa kemampuan baca-tulis sebagai induk bahasa yang digunakan oleh setiap bangsa.

Keaksaraan membantu membentuk kembali kebudayaan sesuai dengan keinginan suatu masyarakat. Oleh karena itu, keaksaraan dibentuk oleh kebudayaan dan keaksaraan pula yang membentuk budaya. Menurut Napitupulu dalam Imawan (2010), keaksaraan didefinisikan sebagai pengetahuan dasar dan keterampilan yang diperlukan oleh semua di dalam dunia yang berubah cepat, merupakan hak asasi manusia. Menurut Hunter dalam Kuswara (2005), terdapat tiga kategori besar tentang definisi keaksaraan. Setiap kategori didasari oleh asumsi yang sangat berbeda dari peran keaksaraan dalam kehidupan setiap individu dalam kehidupan masyarakat. Kategori yang dimaksud yaitu:

1. Literacy as a set of basic a skills, abilities, or competencies. (Keaksaraan merupakan seperangkat keterampilan dan kemampuan atau kompetensi dasar).

2. Literacy as the necessary foundation for a higher 
quality of life. (Keaksaraan sebagai dasar yang penting untuk meningkatkan kualitas kehidupan yang lebih baik).

3. Literacy as a reflection of political and structural realities. (Keaksaraan merupakan refleksi dari kenyataan politik dan struktur).

Konsep keaksaraan terus berkembang dan harus memiliki pendekatan yang lebih baik dari program sebelumnya. Archeir \& Cottingham (1996) menyatakan:

"...the ideological approach as methodology would have to: emphasize writing rather than passive reading of fixed texts; emphasize creative and active involvement of participants; build on existing knowledge of participants, respecting oral traditions and other "literacies": focus on learner generated. Materials (not pre - packaged text): ensure that the process is responsive and relevant to the local context; address the "literacy events" in the wider environment rather than regard literacy as just a classroom activity.

Berdasarkan penjelasan di atas, arah pendekatan dalam keaksaraan adalah (1) menekankan menulis dan membaca pasif dari teks yang sudah ada; (2) menekankan keterlibatan warga belajar secara aktif dan kreatif; (3) membangun pengetahuan, pengalaman, dan memperhatikan tradisi lisan warga belajar dan keaksaraan lain; (4) memusatkan pada bahan belajar yang dihasilkan oleh wajib belajar sendiri; (5) menjamin proses belajar yang responsif dan relevan dengan konteks sosial; serta (6) tempat belajar berada di lingkungan warga belajar bukan di kelas.

Sasaran pendidikan keaksaraan adalah semua orang yang masih buta aksara, melek aksara parsial, dan aksarawan baru. Keseluruhan komunitas sasaran tersebut tidak semua dapat dilayani dengan pembelajaran keaksaraan melalui pendekatan yang sama. Pendekatan pembelajaran keaksaraan harus disesuaikan dengan karakteristik warga belajar dan budaya yang melingkupinya. Menurut Sumardi (2009), filosofi keaksaraan memandang model pembelajaran keaksaraan tergantung dari konteks budaya masyarakat. Artinya pendidikan keaksaraan harus relevan dan sesuai dengan budaya lokal warga belajar.

Komponen program keaksaraan secara mendasar tidak berbeda dengan komponen program-program pendidikan nonformal lainnya. Menurut Sudjana (2001), komponen-komponen tersebut adalah masukan sarana (instrumental input), masukan mentah (raw input), masukan lingkungan (environmental input), proses (process), keluaran (output) dan masukan lain (other input) serta pengaruh (impact) atau outcomes. Masukan sarana antara lain tujuan, kurikulum, pendidik (tutor, pelatih, instruktur, fasilitator), tenaga kependidikan lainnya, tenaga pengelola, sumber belajar, media, fasilitas, biaya, dan pengelolaan program. Masukan mentah yaitu warga belajar dengan berbagai karakteristik yang dimilikinya. Masukan lingkungan meliputi lingkungan keluarga, lingkungan sosial, lapangan kerja, kelompok sosial, dan sebagainya. Termasuk juga lingkungan alam seperti iklim, lokasi, demografi dan termasuk lingkungan daerah/regional, nasional, bahkan internasional. Proses terdiri dari kegiatan belajar mengajar, bimbingan dan penyuluhan, serta evaluasi. Keluaran yaitu kuantitas lulusan yang disertai kualitas perubahan tingkah laku yang didapatkan melalui kegiatan belajar mengajar. Masukan lain meliputi dana, lapangan kerja/usaha, informasi, alat, fasilitas, pemasaran, paguyuban warga belajar, latihan lanjutan, dan bantuan eksternal.

Pengaruh meliputi (a) perubahan taraf hidup yang ditandai dengan perolehan pekerjaan atau berwirausaha, perolehan atau peningkatan pendapatan, kesehatan dan penampilan diri; (b) kegiatan membelajarkan orang lain atau mengikutsertakan orang lain dalam memanfaatkan hasil belajar yang telah dimiliki; serta (c) peningkatan partisipasi dalam kegiatan sosial dan pembangunan masyarakat.

\section{Pengembangan bahan belajar}

Peningkatan hasil belajar pendidikan keaksaraan perlu ditingkatkan kualitasnya. Salah satu komponen penting yang perlu dikembangkan dalam program pendidikan keaksaraan adalah mutu bahan belajar. Bahan belajar pendidikan keaksaraan perlu dirancang sedemikian rupa agar relevan dan fungsional dalam membelajarkan warga belajar, sehingga di samping meningkatkan kemampuan membaca, menulis, berhitung dan berkomunikasi juga mampu memberikan solusi dalam mengatasi permasalahan yang dihadapinya dalam kehidupan sehari-hari.

Bahan belajar atau materi pembelajaran (instructional materials) adalah pengetahuan, keterampilan, dan sikap yang harus dipelajari warga belajar dalam rangka mencapai standar kompetensi yang telah ditentukan (Sudrajat, 2008). Secara terperinci, jenis-jenis materi pembelajaran terdiri dari pengetahuan (fakta, konsep, prinsip, prosedur), keterampilan, dan sikap atau nilai. Kegunaan bahan belajar dalam pendidikan keaksaraan adalah:

1. Sebagai alat bantu bagi tutor membelajarkan membaca, menulis, dan berhitung (calistung) kepada WB

2. Sebagai alat bantu bagi tutor menyampaikan pesan/ materi pembelajaran yang harus dikuasai oleh WB (warga belajar) 
Menurut Ditjen Dikmas Depdiknas (2006), bahan belajar yang baik dalam pendidikan keaksaraan perlu memenuhi persyaratan sebagai berikut.

1. Membangkitkan motivasi belajar warga belajar.

2. Relevan dengan lingkungan dan kehidupan warga belajar.

3. Fungsional dan langsung bermanfaat dalam kehidupan sehari-hari warga belajar.

Prinsip-prinsip dalam pemilihan materi pembelajaran meliputi (a) prinsip relevansi, (b) konsistensi, dan (c) kecukupan. Prinsip relevansi artinya materi pembelajaran hendaknya relevan, memiliki keterkaitan dengan pencapaian standar kompetensi dan kompetensi dasar. Prinsip konsistensi artinya adanya keajegan antara bahan ajar dengan kompetensi dasar yang harus dikuasai siswa. Misalnya, kompetensi dasar yang harus dikuasai siswa empat macam, maka bahan ajar yang harus diajarkan juga harus meliputi empat macam. Prinsip kecukupan artinya materi yang diajarkan hendaknya cukup memadai dalam membantu siswa menguasai kompetensi dasar yang diajarkan.

Penyusunan bahan ajar adalah suatu upaya untuk merumuskan atau merancang materi dan alat yang akan disajikan dalam proses pembelajaran berdasarkan tema-tema yang telah ditetapkan. Dalam proses pembelajaran program keaksaraan dengan menggunakan pendekatan partisipatif, pemilihan tema tidak dapat berdiri sendiri melainkan saling terkait dengan bahan ajar. Oleh karena itu, kedua hal ini merupakan satu kesatuan yang tak terpisahkan dalam proses pembelajaran program keaksaraan.

Secara garis besar langkah-langkah pemilihan bahan ajar meliputi (a) mengidentifikasi aspek-aspek yang terdapat dalam standar kompetensi dan kompetensi dasar yang menjadi acuan atau rujukan pemilihan bahan ajar, (b) mengidentifikasi jenis-jenis materi bahan ajar, (c) memilih bahan ajar yang sesuai atau relevan dengan standar kompetensi dan kompetensi dasar yang telah teridentifikasi tadi, dan (d) memilih sumber bahan ajar.

Bahan belajar keaksaraan akan lebih bermakna jika dilengkapi dengan gambar dan tulisan. Menurut Weidenmann dalam Sapta (2009) menggambarkan bahwa melihat sebuah foto/gambar lebih tinggi maknanya daripada membaca atau mendengar. Melalui membaca yang dapat diingat hanya $10 \%$, dari mendengar yang diingat $20 \%$, dan dari melihat yang diingat $30 \%$. Foto/gambar yang didesain secara baik dapat memberikan pemahaman yang lebih baik. Bahan belajar ini dalam menggunakannya harus dibantu dengan bahan tertulis. Bahan tertulis dapat berupa petunjuk cara menggunakannya dan atau bahan teks.
Banyak hal yang dapat dijadikan sebagai materi dalam proses pembelajaran program keaksaraan yang bersumber dari potensi lingkungan di mana kelompok belajar keaksaraan tersebut berada. Salah satu sumber tema yang dapat dijadikan sebagai bahan dalam proses pembelajaran adalah budaya lokal yang berkembang di lingkungan kelompok belajar. Masyarakat akan merasa tertarik apabila diajak membicarakan tentang budaya yang berkembang di lingkungannya. Budaya lokal adalah budaya atau kebiasaan yang berkembang dan diyakini keberadaannya oleh sekelompok masyarakat di suatu wilayah.

Menurut Koetjaraningrat (2000), budaya lokal terkait dengan istilah suku bangsa. Suku bangsa adalah suatu golongan manusia yang terikat oleh kesadaran dan identitas akan 'kesatuan kebudayaan'. Kondisi geografis dan pola pikir masyarakat sangat mempengaruhi budaya lokal yang berkembang di suatu wilayah. $\mathrm{Hal}$ - hal yang termasuk dalam konteks budaya lokal antara lain upacara adat, cerita rakyat, kesenian, dan sejarah terbentuknya sebuah wilayah atau babat.

\section{Cerita rakyat}

Cerita rakyat merupakan warisan budaya leluhur yang menjadi wahana untuk berkomunikasi antara masyarakat lama dengan masyarakat sekarang. Warisan budaya, menurut Davidson dan Conville (1991) diartikan sebagai 'produk atau hasil budaya fisik dari tradisi yang berbeda dan prestasi-prestasi spiritual dalam bentuk nilai dari masa lalu yang menjadi elemen pokok dalam jati diri suatu kelompok atau bangsa'. Jadi, warisan budaya merupakan hasil budaya fisik (tangible) dan nilai budaya (intangible) dari masa lalu. Nilai budaya dari masa lalu (intangible heritage) inilah yang berasal dari budaya-budaya lokal yang ada di Nusantara, meliputi tradisi, cerita rakyat dan legenda, bahasa ibu, sejarah lisan, kreativitas (tari, lagu, drama pertunjukan), kemampuan beradaptasi, dan keunikan masyarakat setempat (Galla, 2001).

Menurut Bascom (dalam Adicita, 2010), cerita rakyat adalah cerita yang mempunyai ciri-ciri yang mirip dengan mitos, yaitu dianggap benar-benar terjadi, tetapi tidak dianggap suci. Cerita rakyat pada hakikatnya merupakan cerita yang disampaikan kepada orang lain secara lisan (Prasetya, 2010). Tokoh-tokoh dan peristiwa-peristiwa dalam cerita itu dianggap pernah terjadi pada masa yang lampau, atau merupakan hasil rekaan semata-mata karena terdorong ingin menyampaikan pesan atau amanat melalui cerita tersebut. Karena cerita rakyat dituturkan secara lisan maka unsur utamanya adalah bahasa. Dalam cerita rakyat, khayalan manusia memperoleh kebebasan 
yang mutlak, karena di situ ditemukan hal-hal yang tidak masuk akal, yang tidak mungkin ditemui dalam kehidupan sehari-hari (Mudra, 2008). Fenomena tidak dinilai apakah cerita yang disampaikan nyata atau tidak, tetapi harus dilihat bagaimana mitos itu bekerja dalam masyarakat.Masyarakat pemilik/pendukung mitos tidak mempermasalahkan apakah suatu cerita itu nyata atau tidak. Cerita semata-mata dijadikan sarana komunikasi, pengembangan pengetahuan, dan pembentukan perilaku.

Fungsi cerita rakyat selain sebagai hiburan juga bisa dijadikan suri tauladan, terutama cerita rakyat yang mengandung pesan-pesan pendidikan moral (Dedi, 2010). Cerita rakyat berfungsi sebagai penggalang rasa kesetiakawanan di antara warga masyarakat yang menjadi pemilik cerita rakyat tersebut dan sebagai pengokoh nilai-nilai sosial budaya yang berlaku dalam masyarakat. Dalam cerita rakyat terkadang ajaran-ajaran etika dan moral bisa dipakai sebagai pedoman bagi masyarakat.

Cerita rakyat merupakan karya sastra. Sebagai sebuah karya sastra maka cerita rakyat mempunyai struktur cerita yang teratur. Menurut Rukmini (2010), struktur cerita rakyat meliputi isi cerita, tema, alur, tokoh, latar, dan amanat. Sedangkan pendeskripsian nilai edukatif dalam cerita rakyat meliputi nilai pendidikan moral, nilai pendidikan adat, nilai pendidikan agama, nilai pendidikan sejarah, dan nilai pendidikan kepahlawanan.

Analisis Kebutuhan Pengembangan Bahan Belajar Keaksaraan Berbasis Cerita Rakyat Kutai

Komunitas sasaran pendidikan keaksaraan tidak semua dapat dilayani dengan metode dan strategi pembelajaran yang umum dilaksanakan. Hal ini disebabkan karena adanya alasan-alasan khusus seperti adanya faktor-faktor geografis dan hambatan sosial budaya. Termasuk dalam kategori ini adalah masyarakat pedalaman, masyarakat di daerah perbatasan dan masyarakat dengan karakteristik budaya tertentu.

Pembelajaran keaksaraan dengan menggunakan tema budaya lokal diharapkan lebih bermanfaat bagi masyarakat komunitas khusus. Pembelajaran ini akan berhasil jika didukung komponen program yang berkualitas. Salah satu komponen program tersebut adalah keberadaan bahan belajar yang sesuai dengan kebutuhan warga belajar. Tema bahan belajar pendidikan keaksaraan diambil dari budaya lokal warga belajar. Warisan budaya ini berupa hasil budaya fisik (tangible) dan nilai budaya (intangible) dari masa lalu. Nilai budaya dari masa lalu (intangible heritage) ini yang berasal dari budaya-budaya lokal yang ada di nusantara. Salah satu nilai budaya tersebut dapat diperoleh di cerita rakyat. Upaya untuk mendukung keberadaan bahan belajar tersebut adalah dengan pemanfaatan cerita rakyat sebagai medium pembelajaran keaksaraan.

\section{METODE PENELITIAN}

\section{Waktu dan Tempat}

Uji coba materi bahan belajar dilaksanakan selama 6 bulan (Mei-Oktober 2011) di PKBM Puteri Karang Melenu Kab. Kutai Kartanegara. Uji coba produk dilakukan bersamaan dengan pelaksanaan diklat tutor keaksaraan yang diselenggarakan UPTD PKB Prov. Kaltim pada tanggal tahun 2011.

\section{Pendekatan dan Jenis Penelitian Pengembangan}

Pengembangan model bahan belajar keaksaraan berbasis cerita rakyat Kutai Kalimantan Timur menggunakan desain Research and Development (Borg \& Gall, 1989). Pengembangan model ini berorientasi untuk mengembangkan dan memvalidasi produk-produk yang digunakan dalam pendidikan. Model pengembangan bahan belajar keaksaraan yang berbasis cerita rakyat Kutai Kalimantan Timur menggunakan model ADDIE (Analysis, Design, Develop, Implement, Evaluate) yang dikembangkan oleh Reiser dan Mollenda. Model ADDIE terdiri atas lima tahapan: (1) analisis kebutuhan, (2) desain pembelajaran, (3) produksi/ pengembangan media, (4) evaluasi, dan (5) produk akhir.

\section{Prosedur Pengembangan}

Prosedur pengembangan model mencakup tahap-tahap sebagai berikut:

\section{Analisis Kebutuhan}

a. Langkah pertama dalam analisis kebutuhan adalah studi pustaka, dengan tujuan untuk mengumpulkan informasi tentang data dan kondisi buta aksara di provinsi Kalimantan Timur dan secara khusus di kabupaten Kutai Kartanegara. Selain itu juga mempelajari strategi-strategi pendidikan keaksaraan terkait dengan karakteristik warga belajar, kemudian membaca buku/acuan/penelitian \& pengembangan tentang keaksaraan dan pengembangan bahan belajar.

b. Studi lapangan dilakukan untuk melihat secara langsung keadaan kelompok-kelompok belajar keaksaraan, identifikasi cerita rakyat, proses pembelajaran, dan dokumen hasil belajar warga belajar. Untuk ini dilakukan melalui observasi dan wawancara dengan Kepala Sub Bidang PNFI Dinas 
Pendidikan dan Kepala Seksi Pengembangan dan

Pembinaan Permuseuman Dinas Pariwisata.

\section{Desain Pembelajaran}

Pada tahap desain pembelajaran ini dibuat silabus dan rencana pelaksanaan pembelajaran keaksaraan (RPPK) sebagai dasar dalam mengembangkan bahan belajar. Pembuatan silabus dan RPPK ini melalui langkah-langkah (a) mengidentifikasi standar kompetensi, (b) mengidentifikasi karakteristik awal warga belajar, (c) menetapkan kompetensi dasar, (d) merumuskan indikator keberhasilan, (e) mengembangkan tes penilaian, (f) mengembangkan dan memilih materi pembelajaran, serta $(\mathrm{g})$ menyusun strategi pembelajaran.

\section{Produksi/Pengembangan Bahan Belajar}

Tahap produksi/pengembangan bahan belajar ini dilakukan melalui langkah-langkah:

a. Membuat desain bahan belajar

b. Menetapkan jenis cerita rakyat sebagai tema

c. Membuat visualisasi cerita

d. Menyusun materi bahan belajar sesuai cerita

4. Evaluasi

Tahap evaluasi produk dalam pengembangan terdiri dari:

a. Memvalidasi bahan belajar kepada ahli materi dan ahli media, dilanjutkan dengan analisis data dan revisi produk berdasarkan revisi ahli materi dan ahli media.

b. Melakukan uji coba materi, yaitu pada warga belajar keaksaraan, dilanjutkan dengan analisis data, dan revisi materi produk berdasarkan hasil uji coba materi.

c. Melakukan uji coba produk yaitu pada tutor keaksaraan, dilanjutkan dengan analisis data, dan revisi produk berdasarkan hasil uji coba produk.

\section{Produk Akhir}

Produk akhir merupakan hasil akhir dari serangkaian pengembangan bahan belajar keaksaraan berbasis cerita rakyat Kutai Kalimantan Timur dalam bentuk buku yang dilengkapi dengan gambar dan lembar evaluasi yang individual. Dalam kuesioner disediakan lima pilihan untuk memberikan tanggapan tentang kualitas bahan belajar yang dikembangkan, yaitu sangat baik (5), baik (4), cukup (3), kurang (2), dan sangat kurang (1). Jika tutor memberi tanggapan "sangat baik" pada suatu butir pertanyaan/pernyataan, maka skor butir pertanyaan/pernyataan tersebut sebesar "5", demikian seterusnya.

\section{Populasi dan Sampel}

Pengembangan model bahan belajar keaksaraan berbasis cerita rakyat ini tidak menggunakan sampel acak tetapi sampel yang bertujuan (purposive sampling). Sampel diambil berdasarkan pertimbangan tertentu sesuai dengan tujuan uji coba. Jenis sampelnya adalah

1. Warga belajar Pendidikan Keaksaraan PKBM Puteri Karang Melenu Kab. Kutai Kartanegara, merupakan sampel uji coba materi bahan belajar.

2. Tutor Pendidikan Keaksaraan yang mengikuti diklat Keaksaraan, merupakan sampel uji coba produk (bahan belajar).

\section{Teknik Pengumpulan Data}

Metode pengumpulan data yang digunakan berupa observasi, wawancara, dan kuesioner. Observasi dengan menyediakan lembar observasi digunakan untuk mencatat kejadian-kejadian penting dan respon warga belajar/tutor keaksaraan selama kegiatan uji coba berlangsung. Wawancara dilakukan mulai dari awal kegiatan pengembangan model untuk mendapatkan masukan secara langsung dari warga belajar/tutor. Kuesioner digunakan untuk mengukur kemampuan warga belajar dalam penguasaan materi bahan belajar dan kualitas bahan belajar yang dikembangkan dari aspek pembelajaran, isi, dan tampilan . Instrumen pengumpulan data dikembangkan dari (1) indikator penguasaan kemampuan membaca, menulis, berhitung dan berkomunikasi untuk level keaksaraan dasar, dan (2) indikator-indikator kualitas bahan belajar dari aspek pembelajaran, isi, dan tampilan.

Penyusunan kuesioner menggunakan model skala Likert yang dimodifikasi. Setiap butir pernyataan terdiri empat pilihan jawaban yang dibuat secara berjenjang, untuk menilai tingkat penguasaan materi bahan belajar dan memberikan tanggapan tentang produk (bahan belajar) yang dikembangkan.

\section{Teknik Analisis Data}

Data hasil uji coba materi yang meliputi tanggapan ahli materi dan penguasaan kemampuan membaca, menulis, berhitung, dan berkomunikasi, dianalisis secara deskriptif kuantitatif dan diuji beda dengan menggunakan $t$-test for paired samples untuk mengetahui ada tidaknya perbedaan yang signifikan pada saat observasi awal dan akhir

Data hasil uji coba produk adalah berupa tanggapan ahli media dan tutor keaksaraan terhadap kualitas produk yang dikembangkan ditinjau dari aspek pembelajaran, isi, dan tampilan. Data yang berupa komentar, saran revisi dan hasil pengamatan selama proses uji coba dianalisis secara deskriptif kualitatif, dan disimpulkan sebagai masukan untuk merevisi produk yang dikembangkan. Sedang data yang berupa skor tanggapan yang dikumpulkan melalui kuesioner, dianalisis secara deskriptif kuantitatif dengan teknik persentase dan kategorisasi. Langkah-langkah yang 
digunakan untuk memberikan kriteria kualitas terhadap produk yang dikembangkan adalah:

1 Data yang berupa skor tanggapan tutor keaksaraan yang diperoleh melalui kuesioner diubah menjadi data interval.

Sangat Baik $=5(100 \%$ sesuai dengan unsur-unsur yang ada dalam pertanyaan/ pernyataan itu).

Baik $=4(80 \%$ sesuai dengan unsur-unsur yang ada dalam pertanyaan/ pernyataan itu).

Cukup $=3(60 \%$ sesuai dengan unsur-unsur yang ada dalam pertanyaan/ pernyataan itu)

Kurang $=2(40 \%$ sesuai dengan unsur-unsur yang ada dalam pertanyaan/ pernyataan itu)

Sangat Kurang $=1(20 \%$ sesuai dengan unsurunsur yang ada dalam pertanyaan/ pernyataan itu).

Dalam kuesioner disediakan lima pilihan untuk memberikan tanggapan tentang kualitas bahan belajar yang dikembangkan, yaitu sangat baik (5), baik (4), cukup (3), kurang (2), dan sangat kurang (1). Jika tutor memberi tanggapan "sangat baik" pada suatu butir pertanyaan/pernyataan, maka skor butir pertanyaan/pernyataan tersebut sebesar " 5 ", demikian seterusnya.

2. Skor yang diperoleh, kemudian dikonversikan men- jadi data kualitatif skala lima, dengan acuan rumus yang dikutip dari Sukardjo (2005) pada tabel 1.

Tabel 1. Konversi Data Kuantitatif ke Data Kualitatif dengan Skala Lima

\begin{tabular}{|c|l|c|}
\hline Nilai & \multicolumn{1}{|c|}{ Interval Skor } & Kategori \\
\hline A & $\mathrm{X}>\overline{\boldsymbol{X}}_{\mathrm{i}+1,80 \mathrm{SB} \mathrm{i}}$ & $\begin{array}{c}\text { Sangat } \\
\text { baik }\end{array}$ \\
\hline B & $\overline{\boldsymbol{X}}_{\mathrm{i}+0,60 \mathrm{SBi}<\mathrm{X} \leq \overline{\boldsymbol{X}}_{\mathrm{i}}+1,80 \mathrm{SB} \mathrm{i}}$ & Baik \\
\hline C & $\overline{\boldsymbol{X}}_{\mathrm{i}-0,60 \mathrm{SB} \mathrm{i}<\mathrm{X} \leq \overline{\boldsymbol{X}}_{\mathrm{i}}+0,60 \mathrm{SB} \mathrm{i}}$ & Cukup \\
\hline D & $\overline{\boldsymbol{X}}_{\mathrm{i}-1,80 \mathrm{SB} \mathrm{i}<\mathrm{X} \leq \overline{\boldsymbol{X}}_{\mathrm{i}}-0,60 \mathrm{SB} \mathrm{i}}$ & Kurang \\
\hline E & $\mathrm{X} \leq \overline{\boldsymbol{X}}_{\mathrm{i}}-1,80 \mathrm{SB} \mathrm{i}$ & $\begin{array}{c}\text { Sangat } \\
\text { kurang }\end{array}$ \\
\hline
\end{tabular}

Keterangan:

$\overline{\boldsymbol{X}}_{\mathrm{i}}=$ Rerata skor ideal $=1 / 2$ (skor maksimal ideal + skor minimal ideal).

$\mathrm{SBi}=$ Simpangan baku ideal $=1 / 6$ (skor maksimal ideal - skor minimal ideal).

Dalam pengembangan bahan belajar ini, ditetapkan nilai kelayakan produk minimal "C", dengan kategori "cukup", sehingga hasil penilaian, baik dari ahli materi, ahli media, maupun tutor jika sudah memberikan hasil penilaian akhir (keseluruhan) dengan nilai minimal "C" (cukup), maka produk hasil pengembangan tersebut sudah dianggap layak digunakan.

\section{HASIL DAN PEMBAHASAN}

Data yang diperoleh dalam uji coba model digolongkan dalam dua kelompok data, yaitu data uji coba materi, dan uji coba kualitas bahan belajar. Data uji coba materi mencakup data kemampuan awal dan akhir warga belajar serta data observasi pembelajaran yang mencakup data kemampuan tutor dalam menyampaikan bahan belajar keaksaraan berbasis cerita rakyat dan data respon warga belajar dalam pembelajaran. Sedangkan data uji coba kualitas bahan belajar meliputi data kualitas materi, tampilan, fungsi dan bahasa.

\section{Uji Coba Materi}

\section{a. Hasil observasi pembelajaran}

Observasi pembelajaran dilakukan oleh observer independen, artinya pengamat tidak berasal dari tim pengembang model. Observasi meliputi pengamatan kemampuan tutor dalam melakukan pembelajaran dan respon warga belajar. Observasi terhadap kemampuan tutor dimulai dari kegiatan awal pembelajaran yang mencakup kegiatan tutor dalam membantu kesiapan warga belajar dalam mengikuti pembelajaran dengan pendekatan cerita rakyat, tutor ketika memotivasi warga belajar dalam mengikuti pembelajaran dan tutor dalam mengkonfirmasi tema cerita rakyat yang dipelajari.

Kegiatan inti pembelajaran mencakup kegiatan tutor dalam memberikan kesempatan pada warga belajar untuk terlibat dalam pembelajaran, menggali pengetahuan warga belajar tentang cerita rakyat yang dipelajari, membelajarkan materi membaca, membelajarkan materi menulis, membelajarkan materi berhitung dan membantu warga belajar dalam memahami perintah dalam bahan belajar serta ketika membimbing warga belajar yang mengalami kesulitan.

Sedangkan dalam kegiatan akhir, observasi dilakukan pada kegiatan tutor dalam merangkum seluruh materi pembelajaran dalam satu pertemuan dan tutor dalam memotivasi warga belajar untuk mengikuti pertemuan berikutnya.

Hasil observasi awal sampai akhir menunjuk- 
kan bahwa variasi tutor dalam memulai pembelajaran pada kegiatan awal sangat baik. Tutor selalu berusaha untuk menghadirkan objek cerita rakyat Putri Karang Melenu pada warga belajar dan meyakinkan bahwa cerita tersebut dekat dengan kehidupan warga belajar. Dalam kegiatan inti, tutor selalu berusaha untuk melibatkan warga dalam pembelajaran dan pendekatan tutor secara individual menjadikan warga belajar mudah memahami materi dalam bahan belajar walaupun ada sebagian kecil warga yang masih pasif. Sedangkan hasil dari observasi pada kegiatan akhir adalah tutor selalu mengingatkan kembali pada warga belajar untuk hadir pada pertemuan yang akan datang, tetapi tutor belum sering melakukan kegiatan merangkum materi sebagai bentuk penegasan atau kesimpulan.

Observasi warga belajar meliputi (1) respon warga ketika tutor mengkonfirmasi cerita; (2) tutor menjelaskan materi yang akan disampaikan; (3) tutor menggali pengetahuan warga tentang cerita yang akan dipelajari; (4) tutor mendiskusikan cerita rakyat; (5) tutor mengajak warga membaca huruf dan menyusun menjadi suku kata; (6) tutor mengajak warga membaca kata dan memenggal menjadi suku kata dan huruf; (7) tutor mengajak warga menulis huruf, suku kata, dan kalimat; (8) tutor mengajak berhitung dari 1 sampai 10; (9) tutor memberikan pertanyaan, serta (10) tutor menyuruh warga untuk menceritakan kembali.

Hasil observasi warga belajar menunjukkan bahwa dari observasi awal respon warga belajar sangat antusias. Hal ini dapat terlihat dari semangat mengikuti pembelajaran dan berkomentar bahwa bahan belajar ini bagus dan menarik. Pada saat tutor mengkonfirmasi cerita dengan menjelaskan gambar lembusuana, warga serius mendengarkan dan masih melihat-lihat gambar tersebut walaupun tutor sudah masuk ke materi cerita. Dari data warga belajar diperoleh informasi bahwa 9 dari 10 orang warga tidak pernah sekolah dan hanya satu orang yang putus sekolah dasar kelas 1. Dibandingkan kondisi awal tersebut, sebagian besar warga belajar mengalami kemajuan besar dalam kemampuan membaca, menulis, dan berhitung. Sedangkan pada kemampuan berbahasa, warga belajar mengalami sedikit kemajuan. Hal ini lebih disebabkan perasaan malu ketika diminta menceritakan kembali, namun mereka sangat antusias ketika bercerita di antara warga belajar.

b. Kemampuan warga belajar

Responden dalam uji coba materi bahan belajar adalah warga belajar keaksaraan yang berjumlah 10 orang. Pengukuran kemampuan warga belajar mencakup kemampuan membaca, menulis, berhitung, dan berkomunikasi. Indikator kemampuan membaca, menulis, berhitung, dan berkomunikasi disesuaikan dengan standar kompetensi keaksaraan tingkat dasar. Secara detail perbedaan masing-masing kemampuan di pengukuran awal dan akhir dapat terlihat dalam gambar 1, 2, 3, dan 4 .

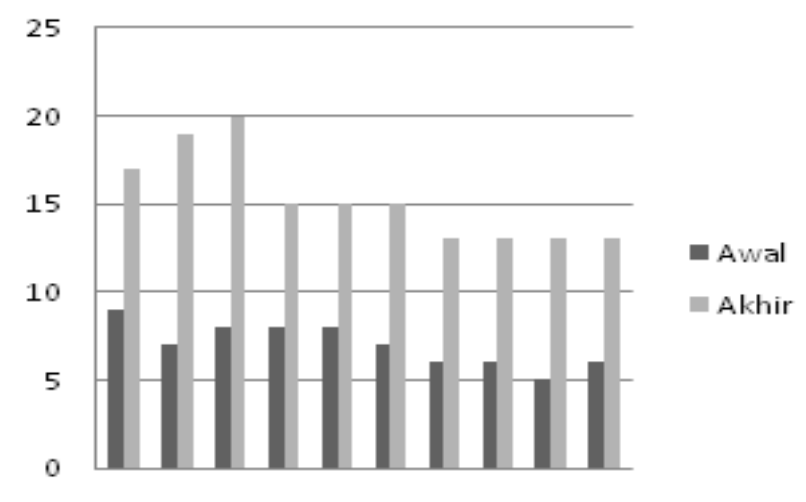

$\begin{array}{lllllllllll}A & B & C & D & E & F & G & H & \text { I } & \text { J }\end{array}$

Gambar 1. Skor Kemampuan Membaca

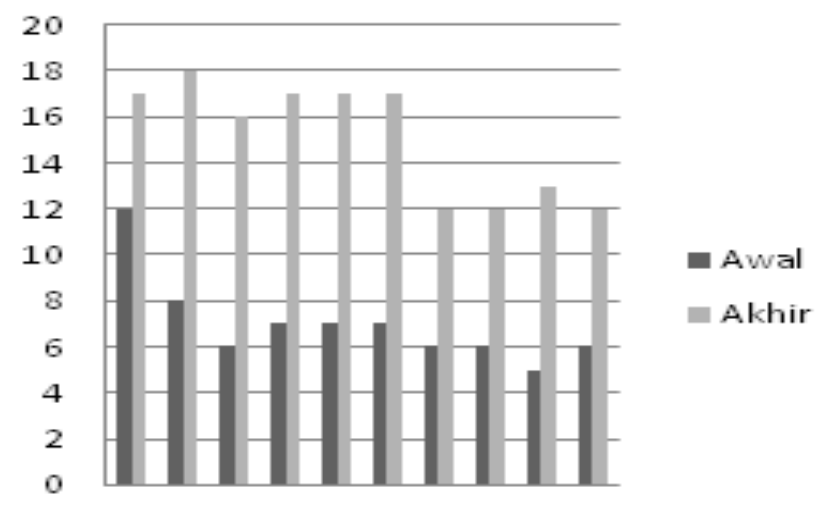

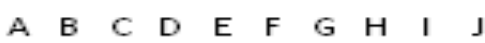

Gambar 2. Skor Kemampuan Menulis

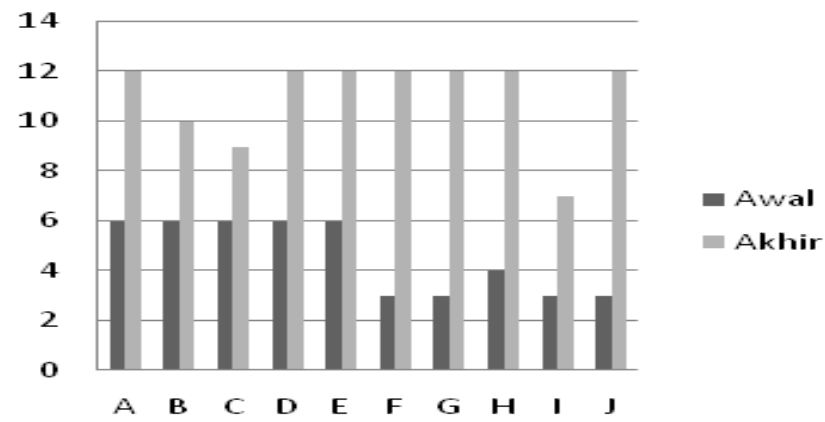

Gambar 3. Skor Kemampuan Berhitung

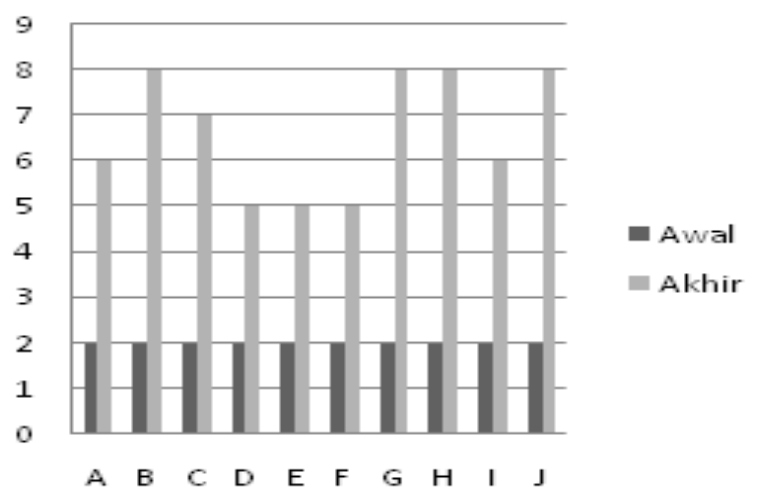

Gambar 4. Skor Kemampuan Berkomunikasi 
Secara keseluruhan, pada tes kemampuan awal warga belajar, skor terendah 15 dan skor tertinggi mencapai 29. Sedangkan pada tes kemampuan akhir, skor terendah 39 dan skor tertinggi mencapai 55 .

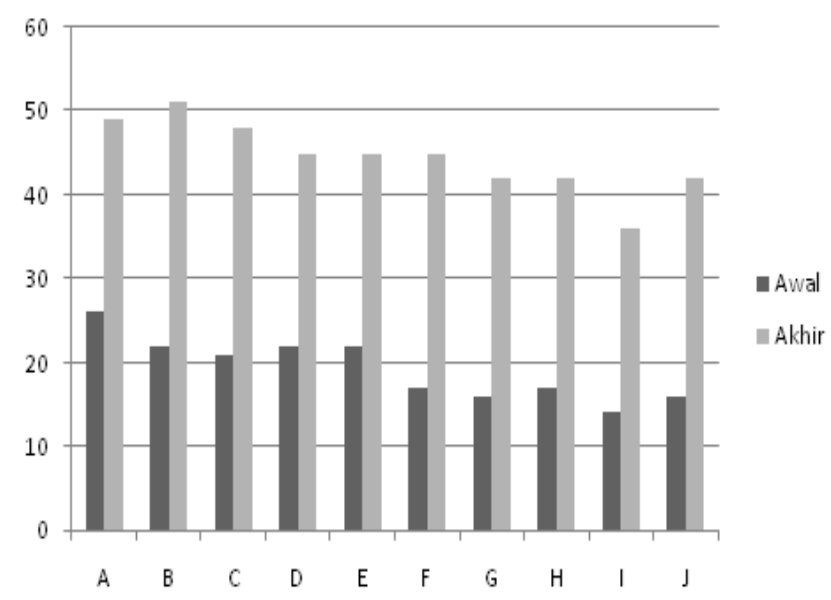

Gambar 5. Skor Kemampuan Warga Belajar dalam Penguasaan Materi Bahan Belajar Keaksaraan Berbasis Cerita Rakyat

Berdasarkan uji beda dengan menggunakan $t$ test for paired samples, perbedaan skor yang dicapai warga belajar signifikan. Dengan selisih rerata antara skor kemampuan awal dan akhir sebesar 25.20 dan derajat kebebasan 9 diperoleh nilai t hitung sebesar 33.28. Pada taraf signifikansi $5 \%$, nilai t tabel adalah
2.262. Karena t hitung $>t$ tabel $(33.28>2.262)$, maka hipotesis nol ditolak artinya terdapat perbedaan yang signifikan antara skor kemampuan awal dan kemampuan akhir warga belajar setelah menggunakan bahan belajar keaksaraan berbasis cerita rakyat. $\mathrm{Hal}$ ini menunjukkan bahwa perubahan pencapaian skor meningkat secara signifikan.

\section{Kualitas Bahan Belajar}

Berdasarkan hasil analisis data tanggapan tutor keaksaraan terhadap kualitas produk dalam uji coba lapangan, ditinjau dari aspek materi, tampilan, fungsi, dan bahasa, secara berturut-turut diperoleh rata-rata skor $37.03,36.66,10.56$, dan 6.36 . Rerata skor ideal masing-masing yang dicapai adalah aspek materi 30 , tampilan 30 , fungsi 7.5 , dan bahasa 5 . Sedangkan simpangan baku ideal masing-masing adalah aspek materi 6 , tampilan 6 , fungsi 1.5 , dan bahasa 1 . Angka ini menurut tabel konversi data kuantitatif ke data kualitatif skala 5 tergolong pada kriteria "sangat baik" untuk aspek fungsi dan kriteria "baik" untuk aspek materi, tampilan dan bahasa. Sesuai dengan kriteria kualitas produk yang telah ditetapkan, yaitu bahwa setiap aspek yang dinilai dalam produk yang dikembangkan dianggap layak jika kriteria yang dicapai minimal "C" atau "cukup", maka bahan belajar keaksaraan berbasis cerita rakyat Kutai ini layak digunakan dalam pembelajaran keaksaraan.

\section{PENUTUP}

\section{Kesimpulan}

Pengembangan model ini menghasilkan produk berupa bahan belajar keaksaraan berbasis cerita rakyat Kutai. Kelengkapan bahan belajar ini meliputi (1) memiliki desain pembelajaran individual sehingga warga belajar dapat belajar secara mandiri; (2) memuat materi pembelajaran terstruktur yang dilengkapi dengan gambar yang menarik sehingga materi calistung menjadi mudah dipelajari; (3) memiliki gambar konfirmasi yang berfungsi untuk menghadirkan objek cerita rakyat dalam kehidupan sehari-hari warga belajar; (4) dilengkapi dengan tujuan belajar, petunjuk belajar, dan petunjuk untuk tutor sehingga memudahkan tutor dan warga belajar dalam menggunakan bahan belajar; dan (5) dilengkapi dengan lembar evaluasi warga belajar individual sehingga kemajuan setiap warga belajar mudah diketahui.

Pada uji coba materi diperoleh hasil bahwa hipotesis nol ditolak artinya terdapat perbedaan yang signifikan antara skor kemampuan awal dan kemampuan akhir warga belajar setelah menggunakan bahan belajar keaksaraan berbasis cerita rakyat. Hal ini menunjukkan bahwa perubahan pencapaian skor meningkat secara signifikan. Sedangkan hasil uji coba kualitas bahan belajar diperoleh hasil bahwa kriteria "sangat baik" untuk aspek fungsi dan kriteria "baik" untuk aspek materi, tampilan, dan bahasa.

\section{Saran}

Berdasarkan hasil pengembangan dapat disarankan hal-hal berikut (1) mengingat masih terbatasnya bahan belajar keaksaraan berbasis cerita rakyat, perlu adanya pengembangan-pengembangan lanjutan baik dari aspek materi, bahasa, fungsi, dan tampilannya; dan (2) perlu adanya pengembangan bahan belajar berbasis cerita rakyat masyarakat yang lainnya selain Kutai, misalnya cerita rakyat Bulungan, Paser atau Dayak. 


\section{DAFTAR PUSTAKA}

Adicita. (2010). Pengertian legenda/cerita rakyat. Diakses dari situs http://www.adicita.com pada tanggal 14 Maret 2011.

Archer, D. \& Cottingham,S. (1996). Regenerated freirean literacy through empowering community techniques. ACTIONAID.

Borg, W.R., \& Gall, M.D. (1989). Educational research: An introduction, Fifth Edition. London: Longman Group Ltd.

Davison, G. \& Conville, C. Mc. (1991). A heritage handbook. St. Leonard, NSW: Allen \& Unwin.

Dinas Pendidikan Kaltim. (2010). Data buta aksara provinsi Kalimantan Timur tahun 2010.

Direktorat Pendidikan Masyarakat. (2005). Acuan bahan belajar pendidikan keaksaraan fungsional. Jakarta: Direktorat Jenderal Pendidikan Luar Sekolah Depdiknas.

Galla, A. (2001). Guidebook for the participation of young people in heritage conservation. Brisbane: Hall and jones Advertising.

Handarini, H. S., dkk. (2009). Kajian fungsional pembelajaran keaksaraan kontekstual di provinsi Jawa Timur.

Imawan, T. (2010). Model kecakapan hidup (lifeskill) pada keaksaraan fungsional. Diakses dari situs http://imadiklus.com pada tanggal 21 Juni 2010.

Isnaini, D. (2010). Cerita rakyat: Pengertian cerita rakyat. Diakses dari situs http://www.dedisnaini. com. pada tanggal 07 April 2011.

Koentjaraningrat.(2000). Kebhinekaan suku bangsa dan kebudayaan Indonesia. Jakarta: Universitas Terbuka.

Kuswara. (2005). Pembelajaran keaksaraan fungsional melalui bahasa ibu dan kontribusinya terhadap pemertahanan bahasa sunda (Studi deskriptif di Kampung Cibago, Desa Manjung, Kec. Cisalak). Tesis Magister Program Studi Pendidikan Bahasa Indonesia UPI.
Mudra, M. A. (2008). Mewariskan cerita rakyat nusantara di tengah pluralisme budaya. Makalah seminar internasional "Tradisi Lisan sebagai Kekuatan Kultural Membangun Peradaban” di Wakatobi Sulawesi Tenggara.

Prasetya, I. (2010). Fungsi cerita rakyat dalam kehidupan sosial budaya. Diakses dari situs http:// inzpirasku.com pada tanggal 07 April 2011.

Rukmini, D. (2010). Cerita rakyat Kabupaten Sragen (Suatu kajian struktural dan nilai edukatif). Surakarta: UNS.

Sapta, A. (2009). Jenis bahan belajar. Diakses dari situs http://andy-sapta.blogspot.com pada tanggal 21 Februari 2011.

Sudjana. (2001). Pendidikan luar sekolah : Wawasan, sejarah perkembangan, falsafah, teori pendukung, azas. Bandung : Falah Production.

Sudrajat, A. (2008). Pengembangan bahan ajar (materi pembelajaran). Diakses dari situs http:// akhmadsudrajat.wordpress.com pada tanggal 21 Februari 2011.

Sukarjo. (2005). Kumpulan materi evaluasi pembelajaran. Diktat Mata Kuliah: Prodi Teknologi Pembelajaran. Pascasarjana Universitas Yogyakarta. Tidak diterbitkan.

Sumardi, K. (2009). Modul TOT pendidikan keaksaraan fungsional. Diakses dari situs http://file. upi.edu/pada tanggal 14 Maret 2011.

Tim Pengembang Bahan Ajar Balitbang Pusat Kurikulum Depdiknas. (2008). Kajian konsep dan kebutuhan lapangan penyusunan model bahan ajar pendidikan nonformal. Jakarta: Depdiknas.

Undang-undang No. 20 tahun 2003 tentang sistem Pendidikan Nasional.

Yunus I., (2000). Penyusunan bahan belajar pendidikan keaksaraan. Jakarta: Direktorat Pendidikan Masyarakat, Ditjen PLSP Depdiknas. 